\title{
One-dimensional $P$-wave velocity structure in the northern Red Sea area, deduced from travel time data
}

\author{
Hesham Mohamed and Kaoru Miyashita \\ Graduate School of Science and Engineering, Ibaraki University, Mito 310-8512, Japan
}

(Received July 10, 2000; Revised April 27, 2001; Accepted April 27, 2001)

\begin{abstract}
Travel time inversion of local earthquake data was used to improve a one-dimensional (1-D) $P$-wave velocity structure model for the northern Red Sea area, including the entrance of the Gulf of Suez and the Gulf of Aqaba. The 1-D velocity model and station corrections were obtained by using $1538 P$-arrivals from 216 well-located earthquakes recorded at ten local seismic stations from August 1994 to January 1999. Earthquakes used in the present study were located in depths less than $28 \mathrm{~km}$ so that the upper $20 \mathrm{~km}$ of the 1-D velocity model was well constrained. The resulting $P$-velocity model indicated velocities from 5.0 to $6.0 \mathrm{~km} / \mathrm{sec}$ down to a depth of 10 $\mathrm{km}$, and velocities from 6.0 to $6.8 \mathrm{~km} / \mathrm{sec}$ with a nearly constant gradient in a depth range from 10 to $20 \mathrm{~km}$. This 1-D velocity model reduced the RMS residual by $47 \%$ from 0.21 to $0.11 \mathrm{sec}$ and improved routine earthquake locations, which clearly indicated clusters of hypocenters in the southern tip of the Sinai Peninsula and the entrance of the Gulf of Suez. The resulting station corrections suggested irregular surface geology in the area. Negative and positive station corrections were obtained; the minimum value $(-0.35)$ was observed at the station MAZR, while the maximum value (0.24) at SHRM.
\end{abstract}

\section{Introduction}

The Red Sea is NNW-SSE trending and bifurcates into the Gulf of Suez and the Gulf of Aqaba in the northern part (Fig. 1(a)). The Red Sea is a divergent plate boundary between the African and Arabian plates (DeMets et al., 1990), which continues northward to the Dead Sea through the Gulf of Aqaba. Mckenzie et al. (1970) proposed an extensional mechanism opening the mouth of the Gulf of Suez. BenMenahem et al. (1976) indicated the approximately northward movement of the Arabian plate relative to the African plate, resulting in the oblique opening of the Red Sea, which is truncated in the northwest by the predominantly shearing force along the Gulf of Aqaba-Dead Sea rift system. Numerous regional studies have been carried out on geotectonics in this area (e.g., Said, 1962; McKenzie et al., 1970; Ben-Menahem and Aboodi, 1971; Maamoun et al., 1976; Daggett et al., 1986; Steckler et al., 1988; Bayer et al., 1988; Salamon et al., 1996).

The distribution of historical and recent earthquakes shows that the tectonic activity is concentrated in the Gulf of Aqaba and the southern part of the Gulf of Suez, that is, near the junction of the tectonic axes of the Suez rift system and the Red Sea divergent boundary. An earthquake $(M s=6.6)$ near the Shadwan Island on March 31, 1969 caused serious damage in the area (Ambraseys et al., 1994). Kebeasy (1990) considered the Gulf of Suez including the Shadwan Island as a part of the most active tectonic region in Egypt. The Hurghada seismic network (Hurukawa et al., 1997) has been established in order to study the seismicity

Copy right (c) The Society of Geomagnetism and Earth, Planetary and Space Sciences (SGEPSS); The Seismological Society of Japan; The Volcanological Society of Japan; The Geodetic Society of Japan; The Japanese Society for Planetary Sciences. and tectonics around the triple junction of the Arabian plate, the African plate and the Sinai subplate (Fig. 1(a)).

We use local earthquake data obtained from the Hurghada seismic network to estimate the 1-D velocity structure and station corrections. The present study is useful for the routine event locations, and for studying the precise seismic activities and tectonics around the northern Red Sea area.

\section{Data of Local Earthquakes}

The data in this study are $P$-wave arrival times of shallow earthquakes recorded by the Hurghada local telemetry seismic network from August, 1994 to January, 1999. The network covers the entrance of the Gulf of Suez, the southern part of the Gulf of Aqaba and the northern part of the Red Sea (Fig. 1(a)). The Hurghada network consists of nine stations with a vertical seismometer and one station with a three-component seismometer, with a natural frequency of $1 \mathrm{~Hz}$. The geographic coordinates of the stations are shown in Table 1. Seismic data at each station are transferred to the Hurghada data center by using FM or PCM transmission technique. All of the data are D/A converted with a GPS clock, and collected at the data center by using the IASPEI software (Lee, 1994). In order to read $P$-wave arrivals, the triggered data are A/D converted again by using a 12-bit digitizer in the PC-SUDS format with a $100 \mathrm{~Hz}$ sampling rate. The network can detect local and regional earthquakes with signal duration magnitude larger than 2.4 , defined as follows:

$$
\begin{aligned}
M= & 2.00 \log T-0.87+0.0035 D \\
& \text { for local events (Lee et al., } 1972) \\
M= & 1.16 \log T+1.13+0.00085 D \\
& \text { for regional events (Maamoun, 1978) }
\end{aligned}
$$




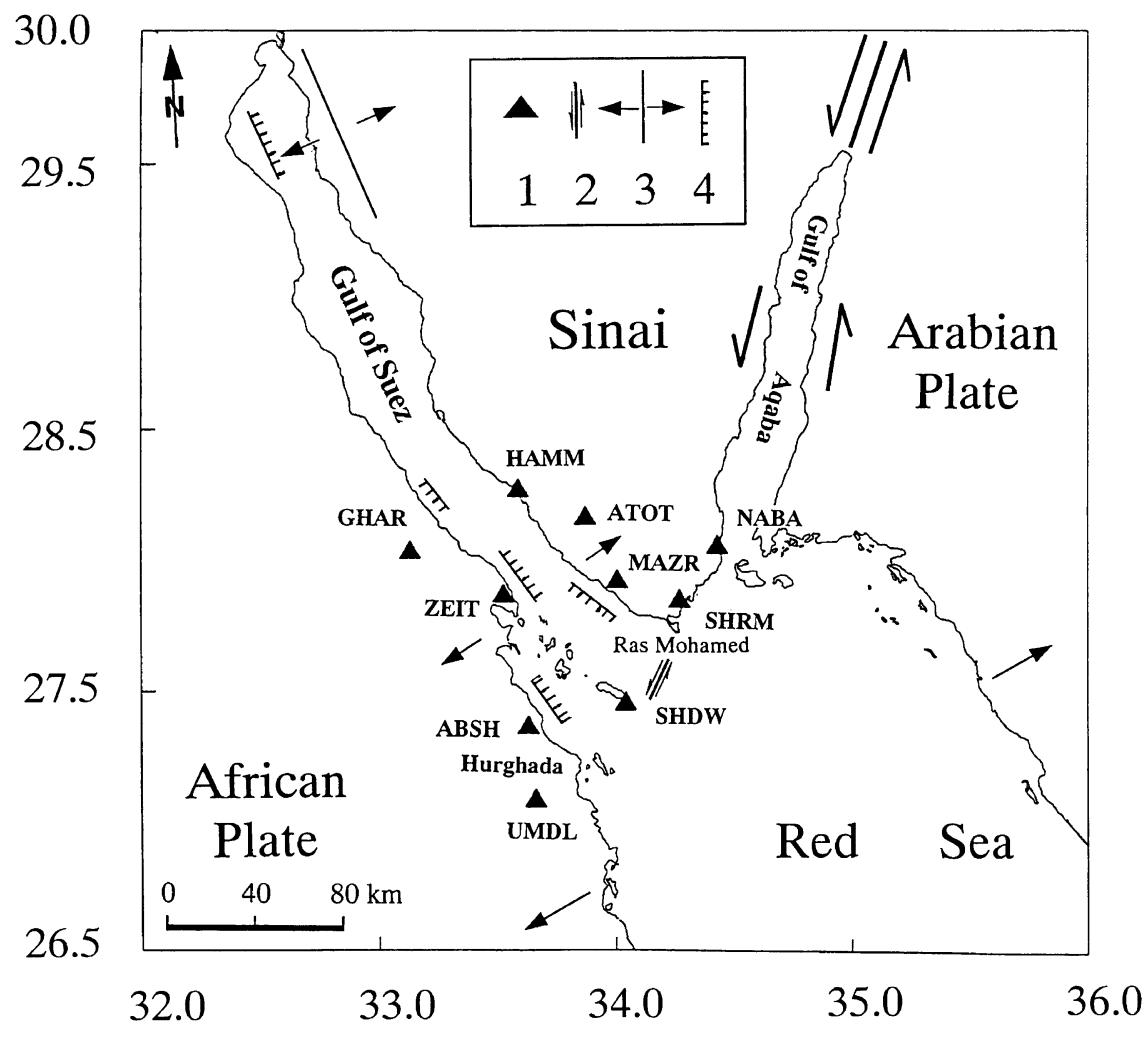

(a)

Fig. 1. (a) Location map of the study area with simplified tectonic features (after Vincent et al., 1987; Colletta et al., 1988; Meshref, 1990). Four symbols in the small box represent seismic station, strike-slip fault, spreading axis and major fault, respectively. The Hurghada network consists of ten seismic stations located along both sides of the southern part of the Gulf of Suez and the northern Red Sea area. The Red Sea is a plate boundary between the African and the Arabian plates. The plate boundary extends northwards to the Gulf of Aqaba that lies east of the Sinai Peninsula. (b) Hypocenter distribution of the earthquakes recorded by the Hurghada seismic network from August 1994 to January 1999, where the E-W cross section is on the lower side and the N-S cross section on the upper right side. Depth and horizontal errors of the hypocenters are relatively small inside the network, while they are relatively large outside the network. A bold cross indicates the hypocenter of a large earthquake in 1995.

Table 1. Locations and station corrections of the Hurghada seismic network.

\begin{tabular}{lccccc}
\hline \multicolumn{1}{c}{$\begin{array}{c}\text { Station } \\
\text { name }\end{array}$} & $\begin{array}{c}\text { Station } \\
\text { code }\end{array}$ & $\begin{array}{c}\text { Longitude } \\
(\mathrm{E})\end{array}$ & $\begin{array}{c}\text { Latitude } \\
(\mathrm{N})\end{array}$ & $\begin{array}{c}\text { Elevation } \\
(\mathrm{m})\end{array}$ & $\begin{array}{c}\text { Station correction } \\
(\mathrm{sec})\end{array}$ \\
\hline Hamm Mosa & HAMM & $33^{\circ} 34.67^{\prime}$ & $28^{\circ} 16.58^{\prime}$ & 241 & +0.07 \\
Atot Mountain & ATOT & $33^{\circ} 51.26^{\prime}$ & $28^{\circ} 10.10^{\prime}$ & 200 & +0.01 \\
Mazria & MAZR & $33^{\circ} 59.69^{\prime}$ & $27^{\circ} 55.75^{\prime}$ & 200 & -0.35 \\
Gabel El-Zeit & ZEIT & $33^{\circ} 30.97^{\prime}$ & $27^{\circ} 52.37^{\prime}$ & 100 & -0.02 \\
Gabel Au-Shaar & ABSH & $33^{\circ} 27.25^{\prime}$ & $27^{\circ} 22.08^{\prime}$ & 220 & +0.10 \\
Wadi Um Dalfa & UMDL & $33^{\circ} 39.10^{\prime}$ & $27^{\circ} 05.16^{\prime}$ & 100 & -0.21 \\
Gharamoul Mountain & GHAR & $33^{\circ} 07.20^{\prime}$ & $28^{\circ} 02.40^{\prime}$ & 350 & +0.07 \\
Sharm El-Sheich & SHRM & $34^{\circ} 25.78^{\prime}$ & $27^{\circ} 85.20^{\prime}$ & 300 & +0.24 \\
Shadwan Island & SHDW & $34^{\circ} 01.92^{\prime}$ & $27^{\circ} 27.48^{\prime}$ & 200 & 0.00 \\
Nabak & NABA & $34^{\circ} 24.99^{\prime}$ & $28^{\circ} 00.88^{\prime}$ & 004 & -0.02 \\
\hline
\end{tabular}

where $M, T$, and $D$ denote the signal duration magnitude, signal duration in seconds and epicentral distance in kilometers, respectively.

Earthquake locations were determined by using the HYPO71 program (Lee and Lahr, 1975). The seismicity recorded by the network during the period from August
1994 to January 1999 is shown in Fig. 1(b). Many earthquakes occurred along troughs of the Red Sea and the Gulf of Suez. Although an earthquake of $M=6.4$ in the Gulf of Aqaba on November 22, 1995 was accompanied with a large number of aftershocks, their locations, especially their depths, were not determined so accurately, because these 


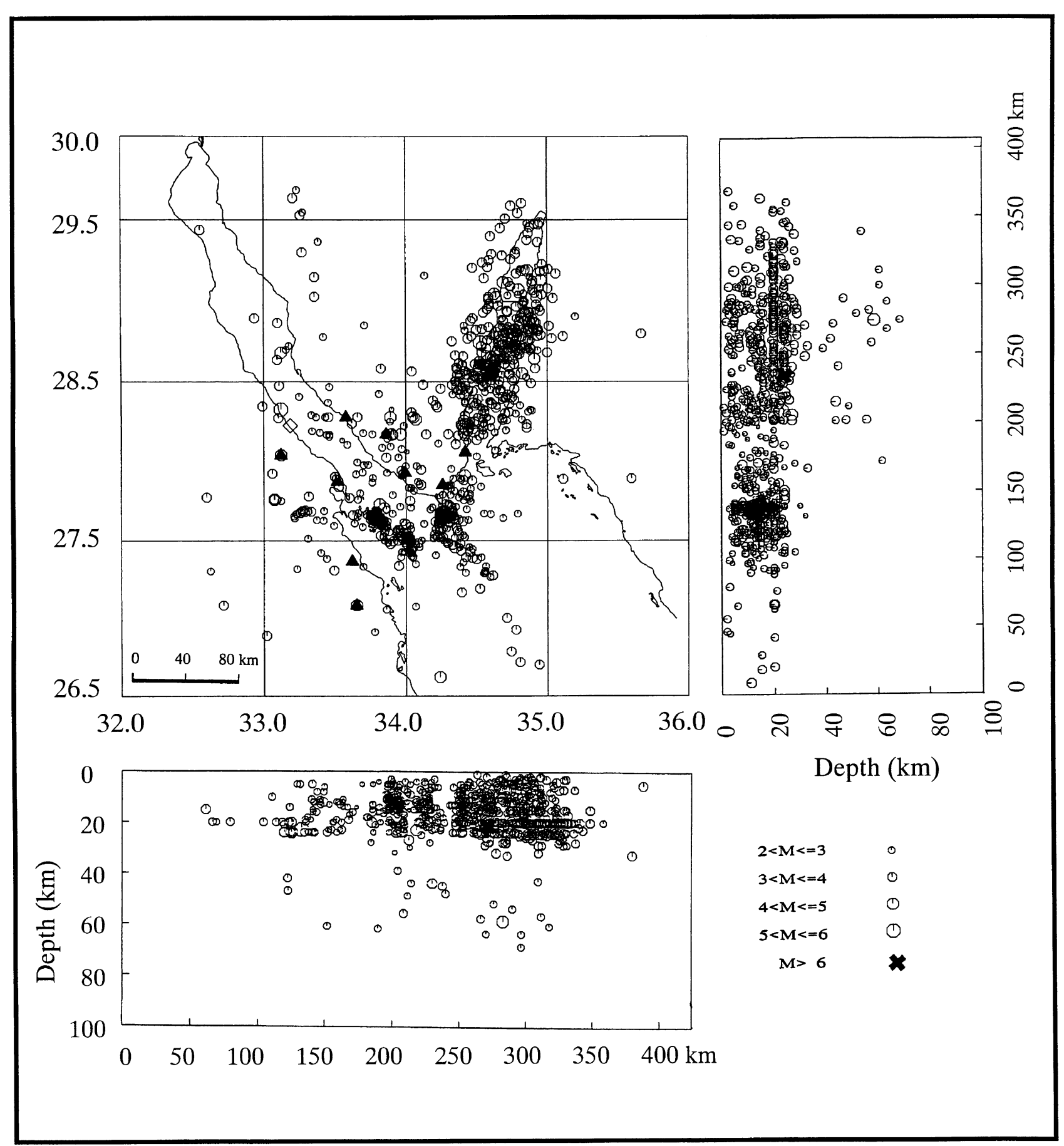

(b)

Fig. 1. (continued).

events occurred outside the Hurghada network.

\section{Method of Local Earthquake Data Inversion}

Interpretation of earthquake data, especially for seismotectonics, strongly depends on the accuracy of earthquake locations. In this study, an inversion technique (Kissling, 1988, 1995) was applied to estimate a more reliable 1-D velocity model with station corrections. The observed arrival time $t_{\mathrm{obs}}$ can be expressed by $t_{\mathrm{obs}}=f(\boldsymbol{s}, \boldsymbol{h}, \boldsymbol{m})$, where $\boldsymbol{s}, \boldsymbol{h}$, and $\boldsymbol{m}$ are the station coordinates, the hypocentral parameters including origin time and the velocity structure model, respectively (Kissling et al., 1994). The function $f$ is a nonlinear function of unknown parameters $h$ and $m$ (Thurber, 1985). Applying the ray theory with an initial velocity model, we can calculate a theoretical arrival time $t_{\text {cal }}$ for each event-station pair. According to Kissling et al. (1994), we can obtain a linear relationship between travel time residual $t_{\text {res }}$ and adjustments of unknown parameters, 


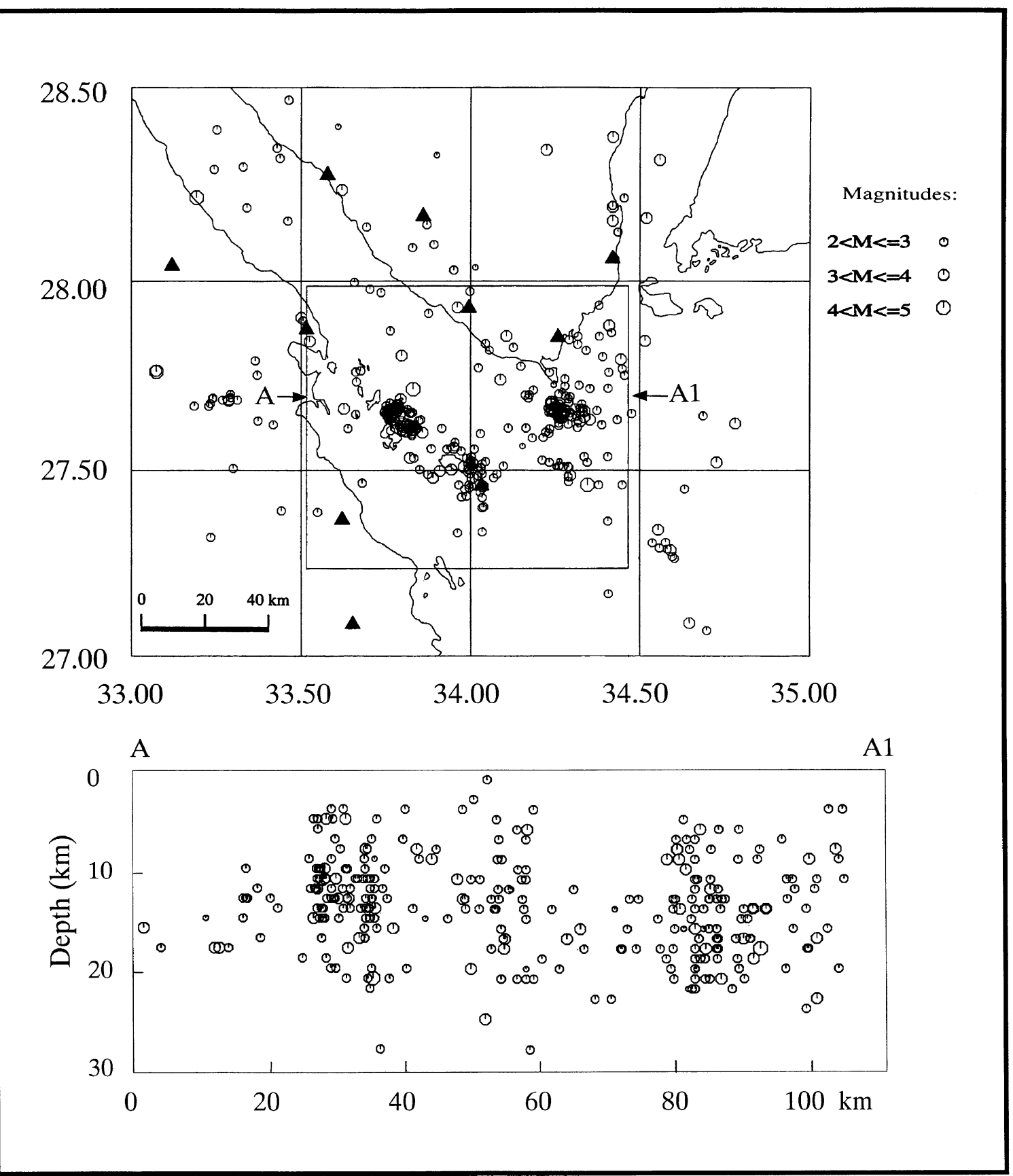

Fig. 2. Earthquakes selected for the present inversion analysis. Circles denote the epicenters and solid triangles the seismic stations. The small rectangle indicates the area, in which we obtained high quality locations. On the lower side, a cross section of the earthquake distribution within the rectangle along A-A1 is shown.

$\Delta h_{k}$ and $\Delta m_{i}$, as follows:

$$
t_{\text {res }}=t_{\mathrm{obs}}-t_{\mathrm{cal}}=\sum_{k=1}^{4} \frac{\partial f}{\partial h_{k}} \Delta h_{k}+\sum_{i=1}^{n} \frac{\partial f}{\partial m_{i}} \Delta m_{i}+e,
$$

where $n$ is the total number of velocity model parameters and $e$ represents all the errors, including the observation error, the calculation error, and the error in the velocity model. A solution for the above coupled hypocenter-velocity parameter equations (Thurber, 1992; Pavlis and Booker, 1983; Roecker, 1981; Ellsworth, 1977) consists of the hypocenter parameters, the velocity model, and the station correc- tions, each of which was estimated by comparing the observed travel times with the calculated ones in a least-square sense.

At first, we selected high-quality $P$-wave arrivals from a large number of observations (more than 10000 arrivals), and collected a priori information about the crustal structure around the study area (e.g., Avedik et al., 1988; Gaulier et al., 1988; Marzouk, 1988; Barakat and Miller, 1984; Makris et al., 1983; Tewfik and Ayyad, 1982; Tramontini and Davies, 1969). Then, we relocated events, as shown in Fig. 2, assuming the initial velocity structure model obtained by Marzouk (1988) (Fig. 3; Table 2). Finally, we estimated 


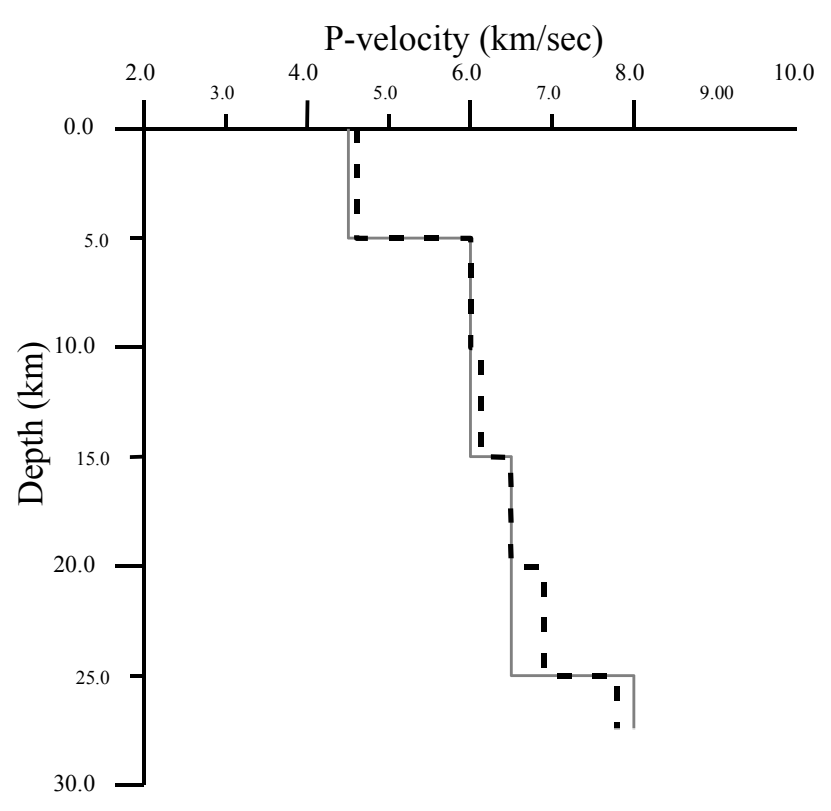

Fig. 3. Initial and final velocity models. The solid line indicates the initial velocity model after Marzouk (1988), middle the dashed line the final one.

Table 2. The initial $P$-wave velocity model.

\begin{tabular}{cc}
\hline Depth range $(\mathrm{km})$ & $P$-velocity $(\mathrm{km} / \mathrm{sec})$ \\
\hline$<5$ & 4.50 \\
$05-15$ & 6.00 \\
$15-25$ & 6.50 \\
$>25$ & 8.00 \\
\hline
\end{tabular}

Table 3. The final $P$-wave velocity model.

\begin{tabular}{cc}
\hline Depth range $(\mathrm{km})$ & $P$-velocity $(\mathrm{km} / \mathrm{sec})$ \\
\hline$<5$ & 4.7 \\
$05-10$ & 6.04 \\
$10-15$ & 6.12 \\
$15-20$ & 6.49 \\
$20-25$ & 6.87 \\
$25-30$ & 7.80 \\
$>30$ & 7.91 \\
\hline
\end{tabular}

a more reliable $P$-wave velocity model and station corrections, using the method of local earthquake data inversion.

\subsection{1-D velocity model and station corrections}

Using 1538 clear $P$-arrivals from 216 well locatable earthquakes, we estimated the 1-D velocity model and station corrections for the study area. Applying the VELEST software (Kissling, 1995), we estimated the velocity model and station coordinates by trial and error. In this process we needed to search for the minimal RMS misfit solution by varying velocity model parameters within a certain reasonable range. After several runs using different initial velocity

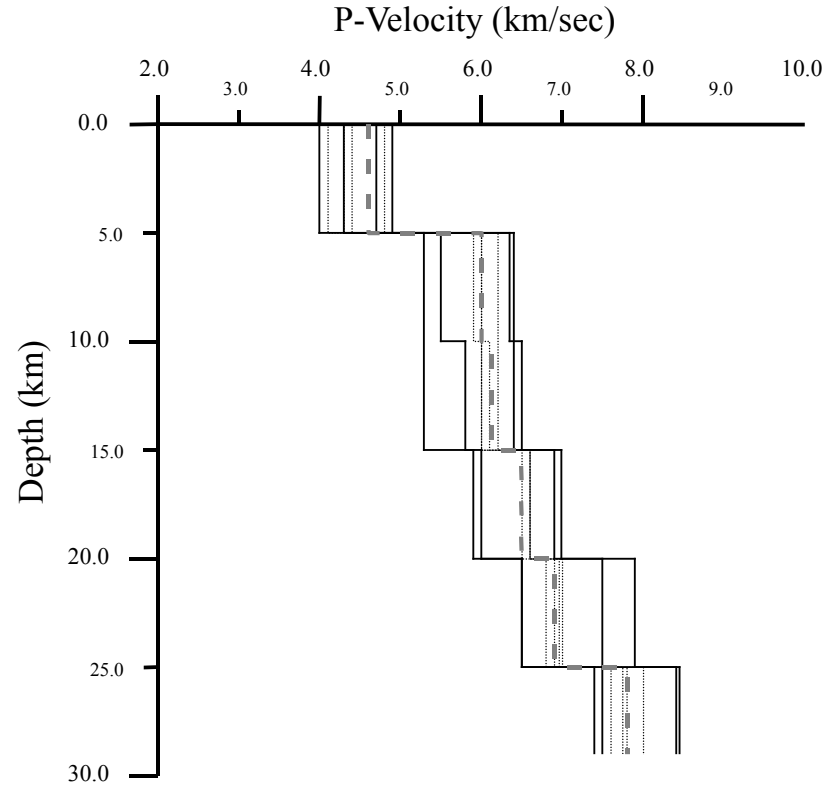

Fig. 4. Stability tests; thin solid lines indicate the different initial models with higher and lower velocities, dotted lines the estimated models, and thick dashed line the final velocity model. The estimated models are almost identical with the final velocity model.

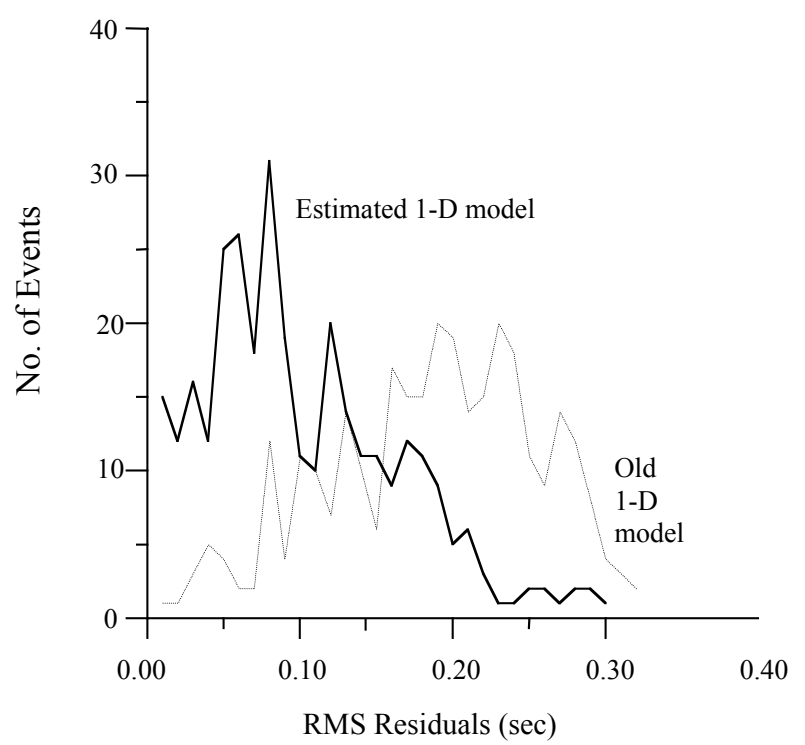

Fig. 5. Distribution of seismic events versus their RMS residuals; the dotted line corresponds to the initial 1-D model, and the solid line the final one. The final velocity model is improved significantly, as shown by considerable reduction of the RMS residuals.

models (varying layer thicknesses and velocities), hypocentral parameters and control parameters, the final 1-D $P$-wave velocity model (Fig. 3; Table 3) was obtained on the basis of the minimum RMS misfit. Although stability tests were carried out by assuming several initial models (with relatively higher or lower velocities, and different layer thicknesses) for the same data set and control parameters (Fig. 4), output velocity models were almost close to the final velocity 


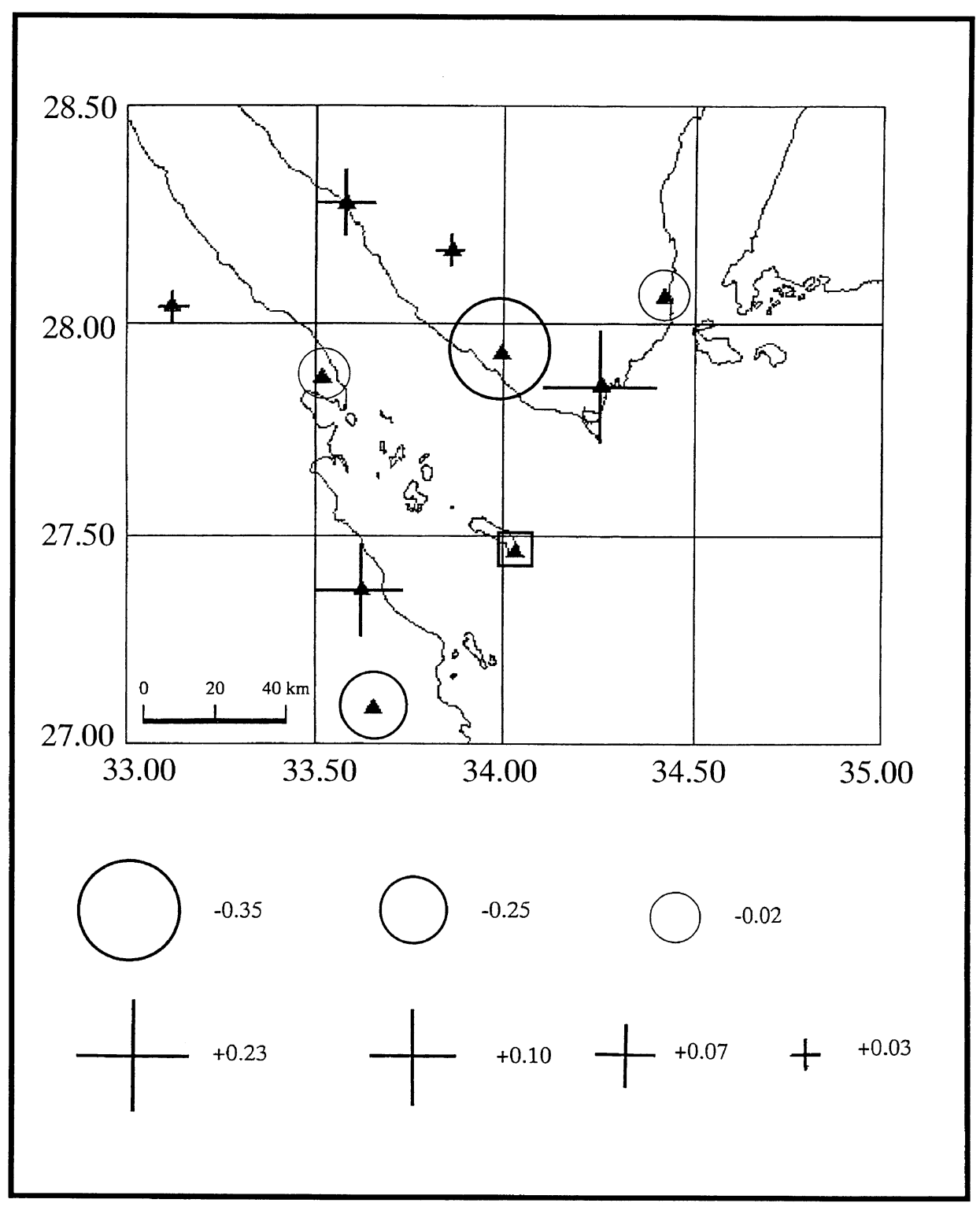

(a)

Fig. 6. (a) Station corrections for the estimated 1-D velocity model. The reference site with a zero station correction is identified by an open square. Sites with negative station corrections are shown by open circles, and sites with positive ones by crosses. (b) Relocated hypocenter distribution of seismic events by using the obtained 1-D velocity model and station corrections. Concentrated seismicity can be recognized around the southern tip of the Sinai Peninsula and the entrance of the Gulf of Suez. The E-W cross section of the event distribution shows that the depths of earthquakes in Ras Mohamed range from 8 to $26 \mathrm{~km}$, and the depths of earthquakes around the Shadwan Island range from 4 to $18 \mathrm{~km}$.

model. The final velocity model was well resolved within a depth interval of $5 \mathrm{~km}$, and the velocities were well constrained for upper layers shallower than a depth of $20 \mathrm{~km}$, while they were poorly constrained below a depth of $25 \mathrm{~km}$, because most of the earthquakes occurred at shallow depths in the entrance of the Red Sea area. The estimated 1-D velocity model and station corrections reduced the RMS residual from 0.21 to $0.11 \mathrm{sec}$. As shown in the event distribution versus RMS residuals (Fig. 5), the estimated velocity model is much better than the old one. The model indicates velocities from 4.7 to $6.0 \mathrm{~km} / \mathrm{sec}$ at depths less than $10 \mathrm{~km}$, and a velocity of $6.8 \mathrm{~km} / \mathrm{sec}$ at a depth of $20 \mathrm{~km}$.

Station corrections generally depend on local geology, azimuths, and hypocentral distances between observation sta- tions and events. Figure 6(a) shows the resulting station corrections relative to the reference station (SHDW) located in the central part of the area that has a large number of observations with a good coverage in azimuth and hypocentral distance. The distribution of positive and negative values (Table 1) reflects lateral variation in shallow subsurface structure; the positive value $(0.24)$ at the SHRM station is probably due to the thick sediment around this station. Positive station corrections at SHRM, HAMM, ATOT, ABSH, and GHAR indicate slower true velocity than the model velocity. On the other hand, negative station corrections at MAZR, ZEIT, UMDL, and NABA, imply true faster velocity than the model velocity. 


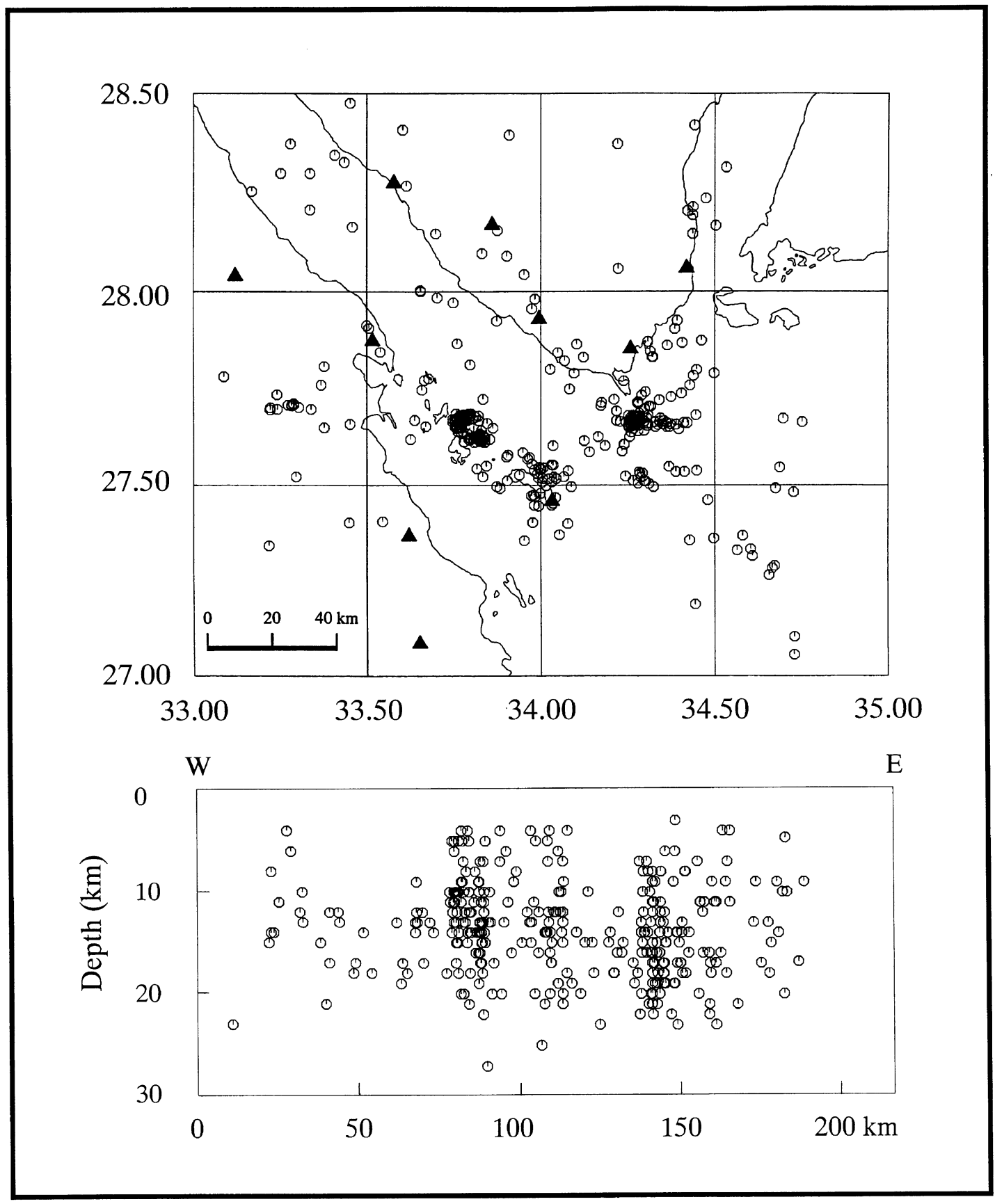

(b)

Fig. 6. (continued).

\section{Discussion and Conclusion}

High seismic activity in the northern Red Sea area has been concentrated near the Shadwan Island, around which a large earthquake $(M s=6.6)$ occurred in 1969. Relocations of seismic events by using the estimated 1-D velocity model and station corrections revealed the depth range of earthquakes around the Shadwan Island from 4 to $18 \mathrm{~km}$ (Fig. 6(b)). The present study also indicated the concentrated seismicity in the south of Ras Mohamed (Fig. 1(a)) ranged from 8 to $26 \mathrm{~km}$ in depth. Although similar result has been obtained by Hurukawa et al. (2001), we showed several earthquake swarms near the entrance of the Gulf of Suez and the southern tip of the Sinai Peninsula, where the trough of the Red Sea ends. Concerning the present study area, the $P$-wave velocity model improved the routine earthquake locations by the Hurghada seismic network, as shown by considerable reduction of RMS misfit from 0.21 to $0.11 \mathrm{sec}$.

Several studies have been carried out to investigate the crustal structure in and around the study area. The crustal structure appears to be inhomogeneous, and the Moho depth is $20 \mathrm{~km}$ near the shore line area and ranges from 35 to 40 $\mathrm{km}$ in the inland area (e.g., Tramontini and Davies, 1969; Makris et al., 1983; Hosney, 1985). On the other hand, Avedik et al. (1988) and Gaulier et al. (1988) have estimated 
the Moho depth to be between 11.5 and $18 \mathrm{~km}$ on the basis of refraction studies. The present study showed $4.7 \mathrm{~km} / \mathrm{sec}$ of a $P$-wave veolocity for the uppermost layer, $6.4 \mathrm{~km} / \mathrm{sec}$ at a depth of $15 \mathrm{~km}$, and $6.8 \mathrm{~km} / \mathrm{sec}$ at $20 \mathrm{~km}$. The average Moho depth is deeper than $20 \mathrm{~km}$ in the study area.

We have recognized that the velocity structure is varying both horizontally and vertically from the Sinai coastal plain to the northern Red Sea area. We need more detailed studies on the crustal structure in this area, for example, our ongoing earthquake tomographic analysis.

Acknowledgments. The authors wish to express their sincere appreciation to all of the Japanese staff for their installation and operation of the Hurghada seismic network. The project was funded by Japan International Cooperation Agency (JICA), and carried out with the cooperation of Japan and Egypt (National Research Institute of Astronomy and Geophysics, NRIAG). We wish to thank all the Egyptian groups for their operation and providing us with data. We gratefully thank Prof. E. Kissling for his helpful advice. We also appreciate the comments of two anonymous referees, which greatly improved the manuscript.

\section{References}

Ambraseys, N. N., C. P. Melville, and R. D. Adams, The Seismicity of Egypt, Arabia and the Red Sea, 173 pp., Cambridge University Press, Cambridge, 1994.

Avedik, F., L. Geli, J. M. Gaulier, and J. P. le Formal, Results from three refraction profiles in the Northern Red Sea (above $25^{\circ}$ ) recorded with Ocean Bottom Vertical Seismic array, Tectonophys., 153, 89-101, 1988.

Barakat, H. and P. Miller, Geology and petroleum exploration, Safaga concession, North Red Sea, Egypt, 7th E.G.P.C., Cairo, March 1984, 24 pp., 1984.

Bayer, H. J., H. Hotzl, A. R. Jado, B. Rocher, and W. Voggenreiter, Sedimentary and structural evolution of northwest Arabian Red Sea margin, Tectonophys., 153, 137-151, 1988.

Ben-Menahem, A. and E. Aboodi, Tectonic pattern in the northern Red Sea region, J. Geophys. Res., 76, 2674-2689, 1971.

Ben-Menahem, A., A. Nur, and M. Vered, Tectonics, seismicity and structure of the Afro-Eurasian junction - the breaking of an incoherent plate, Phys. Earth Planet. Inter., 12, 1-50, 1976.

Colletta, A., P. Le Quellec, J. Letouzey, and I. Moretti, Longitudinal evolution of the Suez rift structure (Egypt), Tectonophys., 153, 221-233, 1988.

Daggett, P., P. Morgan, F. K. Boulos, S. F. Hennin, A. A. El-Sherif, A. A. El-Sayed, N. Z. Basta, and Y. S. Melek, Seismicity and active tectonics of the Egyptian Red Sea margin and the northern Red Sea, Tectonophys., 125, 313-324, 1986.

DeMets, C., R. G. Gordon, D. F. Argus, and S. Stein, Current plate motion, Geophys. J. Int., 101, 425-478, 1990.

Ellsworth, W. L., Three dimensional structure of the crust and mantel beneath the island of Hawaii, Ph.D. thesis, Mass. Inst. of Technol., Cambridge, 1977.

Gaulier, J. M., X. Le Pichon, N. Lyberis, F. Avedik, L. Geli, and I. Moretti, Seismic study of the crust of the northern Red Sea and Gulf of Suez, Tectonophys., 153, 55-88, 1988.

Hosney, H. M., Geophysical investigation of the Gulf of Suez-Consequence for tectonic evolution of the Northern Red Sea, 188 pp., Diss., Univ. Kiel, 1985.

Hurukawa, N., H. Murakami, N. Seto, I. Marzouk, A. Megahed, and E. Ibrahim, Establishment of the Seismological Telemetric Network at the southern part of the Gulf of Suez and the northern Red Sea, Second International Scientific Conference, Faculty of Science, Al-Azhar Univ.,
Cairo, Egypt, 17-20, March, 1997.

Hurukawa, N., N. Seto, H. Inoue, K. Nishigami, I. Marzouk, A. Megahed, E. M. Ibrahim, H. Murakami, M. Nakamura, T. Haneda, S. Sugiyama, T. Ohkura, Y. Fujii, H. M. Hussein, A. S. Megahed, H. F. Mohammed, R. Abdel-Fattah, M. Mizoue, S. Hashimoto, M. Kobayasi, and D. Suetsugu, Seismological observation in and around the southern part of the Gulf of Suez in Egypt, Bull. Seismol. Soc. Amer, 2001 (in press).

Kebeasy, R. M., The Geology of Egypt, edited by R. Said, pp. 51-95, A. A. Balkema, Rotterdam, Netherlands, 1990.

Kissling, E., Geotomography with local earthquake data, Rev. Geophys., 26, 659-698, 1988.

Kissling, E., Velest Users Guide, Internal report, Institute of Geophysics, ETH Zurich, 26 pp., 1995.

Kissling, E., W. L. Ellsworth, D. Eberhart-Phillips, and U. Kradolfer, Initial reference model in seismic tomography, J. Geophys. Res., 99, 1963519646, 1994.

Lee, W. H. K., Realtime seismic data acquisition and processing, IASPEI Software Library, Vol. 1, 2nd ed., IASPEI, 1994.

Lee, W. H. K. and J. C. Lahr, HYPO71: A computer program for determining hypocenter, magnitude, and first motion pattern of local earthquakes, U. S. Geol. Surv. Open File Rep., 75, 311, 1975.

Lee, W. H. K., R. E. Bennett, and K. L. Meagher, A method of estimating magnitude of local earthquakes from signal duration, Geol. Surv. OpenFile Rep., 28, 1972.

Maamoun, M. E., Helwan seismic magnitude scale, Bull. Helwan Observatory, No. 196, 1978.

Maamoun, M. and H. M. El Khashab, Seismic studies of the Shadwan (Red Sea) earthquake, Bull. Helwan Inst. Astr. and Geophys., No. 171, 1976.

Makris, J., A. Allam, T. Moktar, A. Basahel, G. A. Dehghani, and M. Bazari, Crustal structure at the northwestern region of the Arabian shield and its transition to the Red Sea, Bull. Fac. Earth Sci., K. Abdulaziz Univ., 6, 435-447, 1983.

Marzouk, I., Crustal structure of Egypt deduced from deep seismic and gravity data, Ph.D. thesis, 118 pp., Univ. of Hamburg, Germany, 1988.

Mckenzie, D., D. Davies, and P. Molnar, Plate tectonics of the Red Sea and East Africa, Nature, 226, 243-248, 1970.

Meshref, W. M., Tectonic framework of Egypt, in The Geology of Egypt, edited by R. Said, pp. 113-155, A. A. Balkema, Rotterdam, Netherlands, 1990.

Pavlis, G. L. and J. R. Booker, A study of the importance on nonlinearity in the inversion of earthquake arrival time data for velocity structure, $J$. Geophys. Res., 88, 5047-5055, 1983.

Roecker, S. W., Seismicity and tectonics of the Pamir-Hindu Kush region of central Asia, Ph.D. thesis, Mass. Inst. of Technol., Cambridge, 1981.

Said, R., The Geology of Egypt, Elsevier, Amsterdam, 377 pp., 1962.

Salamon, A., A. Hofstetter, Z. Garfunkel, and H. Ron, Seismicity of eastern Mediterranean region: Perspective from the Sinai subplate, Tectonophys., 263, 293-305, 1996.

Steckler, M. S., F. Berthelot, N. Lyberis, and X. Le Pichon, Subsidence in the Gulf of Suez: implications for rifting and plate kinematics, Tectonophys., 153, 249-270, 1988.

Tewfik, N. and M. Ayyad, Petroleum exploration in the Red Sea Shelf of Egypt, 6th E.G.P.C, Cairo, March 1982, 30 pp., 1982.

Thurber, C. H., Nonlinear earthquake location: Theory and examples, Bull. Seismol. Soc. Amer., 75, 779-790, 1985.

Thurber, C. H., Hypocenter velocity structure coupling in local earthquake tomography, Phys. Earth Planet. Inter., 75, 55-62, 1992.

Tramontini, C. and D. Davies, A seismic refraction survey in the Red Sea, Geophys. J. R. Astron. Soc., 17, 2225-2241, 1969.

Vincent, C., A. Rolando, and T. Paul, The Sinai triple junction revisited, Tectonophys., 141, 181-190, 1987.

H. Mohamed (e-mail: hesham@mcs.ipc.ibaraki.ac.jp) and K. Miyashita 